\title{
FAKTOR KUNCI KEBERHASILAN MANAJEMEN RANTAI PASOKAN PENANGANAN BENCANA ALAM DALAM PERSPEKTIF PEMERINTAH
}

\author{
Poppy Laksita Rini \\ Universitas Ahmad Dahlan \\ poppy.rini@mgm.uad.ac.id
}

\begin{abstract}
Disaster supply chain management is different from the supply chain management of commercial organization because of the high level of uncertainty. The high level of uncertainty significantly affects the availability of logistic supplies that are needed by the victims of the disaster. This study discovers the key success factors of the disaster supply chain management based on the perspective of the government. This research specifically studies the Government of the Daerah Istimewa Yogyakarta that are represented by Badan Penanggulangan Bencana Daerah (BPBD). Due the fact that Yogyakarta as one of the regions that have the high risk of catastrophic nature in Indonesia. The study will be carried out in a qualitative methodology by conducting deep interview with the Representative of Logistics Department in BPBD. The results of in-depth interviews with four representative of BPBD found that there are six key success factors of disasater management supply chain management which are : (1) Quality of the TRC Team Assessment Results; (2) BPBD Coordination with Government and NonGovernment; (3) Effective Rules and Regulations; (4) Character and Attitude of the Community in Dealing with Disasters; (5) BPBD Warehouse Inventory Management; (6) Management Information Systems and Data Updates.
\end{abstract}

Keywords: Humanitarian Supply Chain Management; Disaster Supply Chain Management; The Local Board for Disaster Management (BPBD).

\begin{tabular}{l}
\hline PENDAHULUAN \\
Manajemen rantai pasokan pada \\
operasi bantuan bencana membutuhkan \\
perlakuan yang berbeda dari organisasi \\
komersial, karena kondisi operasional yang \\
sangat dinamis, sumber daya manusia dan \\
peralatan yang terbatas, tingkat \\
ketidakpastian yang tinggi, dan intervensi \\
berbagai pemiliki kepentingan (Tomasinia, \\
2009). Ketidakpastian kondisi operasional \\
ini membuat operasional penanganan \\
bencana alam sering berjalan tidak
\end{tabular}

terkoordinasi. Di bawah kondisi operasinal yang tidak pasti dan sangat dinamis, manajemen rantai pasokan bantuan bencana alam memerlukan desain rantai pasokan yang fleksibel untuk mampu menyesuaikan kondisi yang berubah (Gattorna, 2006). Desain rantai pasokan yang fleksibel juga diperlukan karena para pemangku kepentingan dalam operasi bantuan terus tumbuh dan berubah selama siklus hidup bencana. Untuk menciptakan operasional bantuan bencana yang efektif, pemangku kepentingan yang terlibat harus mengidentifikasi faktor kunci keberhasilan 
dari manajemen rantai pasokan bencana alam. Dengan demikian, di bawah ketidakpastian yang tinggi dan kondisi penuh tekanan, operasional manajemen rantai pasokan mampu lebih difokuskan pada keputusan yang mengarah pada faktor penentu keberhasilan tersebut.

Salah satu pemangku kepentingan terpenting dalam operasinal bantuan bencana adalah pemerintah. Pemerintah bertanggung jawab atas pusat koordinasi dan operasi selama seluruh siklus hidup bencana. Berdasarkan Peraturan Pemerintah nomor 24 tahun 2007 tentang Operasi Bantuan Bencana, Pemerintah Indonesia membentuk Badan Nasional Penanggulangan Bencana (BNPB) untuk mengelola dan mengoordinasikan penanggulangan bencana alam sejak tahap mitigasi hingga tahap rehabilitasi. Sementara di tingkat bencana lokal, BNPB dibantu oleh pemerintah daerah bernama Badan Penanggulangan Bencana Daerah (BPBD).

Penelitian ini bertujuan untuk mengidentifikasi menemukan faktor kunci keberhasilan untuk manajemen rantai pasokan bantuan bencana khususnya di Daerah Istimewa Yogyakarta berdasarkan perspektif pemerintah yang diwakili oleh BPBD Provinsi dan BPBD Kabupaten atau Kota. Berdasarkan identifikasi bahaya alam Indonesia, Provinsi Daerah Istimewa Yogyakarta memiliki kondisi geografis, geologis, hidrologi, klimatologis, dan demografis yang rentan terhadap ancaman bencana. Sejumlah bencana yang dialami oleh wilayah ini telah menyebabkan kematian, membawa kerugian materi yang sangat besar, menghancurkan hasil pembangunan dan membuat ratusan ribu bahkan jutaan orang miskin dalam sekejap. Gempa bumi yang melanda Yogyakarta dan Jawa Tengah pada bulan Mei 2006, menyebabkan kerugian lebih dari 29 triliun rupiah, tidak termasuk kerugian berikut seperti hilangnya peluang dan mata pencaharian. Meskipun studi ini hanya difokuskan pada operasinal bantuan bencana pada pemerintah Provinsi Daerah Istimewa Yogyakarta, temuan penelitian ini diharapkan dapat diterapkan di daerah atau provinsi lain yang memiliki risiko bencana alam yang tinggi seperti provinsi Daerah Istimewa Yogyakarta.

\section{REVIEW LITERATUR}

\section{Landasan Teori}

Manajemen operasi adalah serangkaian aktivitas yang menghasilkan nilai dalam bentuk barang dan jasa dengan mengubah input menjadi output (Heizer dan Render, 2011). Banyak perusahaan menerapkan teknik yang ada dalam manajemen operasi dikarenakan adanya kesadaran tentang pentingnya perhatian pada proses produksi guna meningkatkan nilai produksi dan mendapatkan laba (Heizer dan Render, 2011). Salah satu komponen penting yang menjadi pembahasan dalam teknik manajemen operasi adalah manajemen logistik yang kemudian berkembang menjadi manajemen rantai pasokan.

Manajemen rantai pasokan adalah integrasi aktivitas pengadaan bahan dan pelayanan, pengubahan menjadi barang setengah jadi dan produk akhir, serta pengiriman ke pelanggan. Seluruh aktivitas ini mencakup aktivitas pembelian dan pengalihdayaan (outsourcing), ditambah fungsi lain yang penting bagi hubungan antara pemasok dengan distributor. Suatu perusahaan yang menerapkan konsep manajemen rantai pasokan yang benar dan baik akan dapat memberikan dampak peningkatan keunggulan kompetitif terhadap produk maupun pada sistem rantai pasokan yang dibangun perusahaan tersebut (Heyzer dan Render, 2011). Lebih lanjut Heyzer dan Render (2011) menyatakan bahwa perusahaan perlu mempertimbangkan masalah rantai pasokan untuk memastikan bahwa rantai pasokan mendukung strategi perusahaan.

Tujuan dari manajemen rantai pasokan adalah untuk mengkoordinasi kegiatan 
dalam rantai pasokan untuk memaksimalkan keunggulan kompetitif dan manfaat dari rantai pasokan bagi konsumen akhir. Seperti tim kejuaraan, fitur utama dari rantai pasokan yang sukses adalah anggota-anggota yang berperan demi kepentingan timnya (rantai pasokan). Manajemen rantai pasokan dalam operasi bantuan bencana, juga dikenal sebagai logistik kemanusiaan, didefinisikan sebagai proses perencanaan, implementasi dan pengendalian yang efisien, hemat biaya distribusi dan penyimpanan barang serta informasi terkait dari titik asal ke titik konsumsi untuk tujuan mengurangi penderitaan korban bencana (Tomasinia, 2009).

UNDP (1993) mengungkapkan bahwa masih sedikitnya studi penelitian tentang manajemen rantai pasokan dalam operasi bantuan bencana karena beberapa alasan. Pertama, sifat logistik yang beragam dalam operasi bantuan bencana tidak sepenuhnya dipahami. Kedua, respons krisis bencana relatif bersifat jangka pendek dan pembentukan rantai pasokan yang efektif membutuhkan waktu di bawah kondisi stres yang tinggi. Ketiga, adanya unsur "we know the best" (kita tahu yang terbaik) yaitu unsur tidak ingin atau tidak mau belajar dari pihak lain yang terlibat dalam operasional bantuan bencana. Hal ini didukung oleh Schulz (2007) yang menemukan bahwa sebagian besar lembaga bantuan yang akhirnya berhasil dalam memberikan bantuan tidak memiliki kemauan untuk mempertimbangkan pendekatan yang digunakan oleh lembaga bantuan lain. Manajemen rantai pasokan seringkali merupakan elemen terbesar dan paling kompleks dari operasi bantuan bencan alam (UNDP, 1993). Agar rantai pasokan menjadi efektif, perlu pemahaman yang jelas tentang faktor penentu keberhasilan. Peningkatan efisiensi rantai pasokan bencana alam mensyaratkan kondisi ketidakpastian untuk dikurangi, diminimalkan, atau bahkan dihilangkan, tetapi dalam banyak kasus bisnis hal ini tidak sepenuhnya dapat tercapai (Christopher, 2001).

\section{Faktor Kunci Kesuksesan Manajemen Rantai Pasokan}

Konsep faktor keberhasilan pertama kali dikembangkan oleh Daniel (1961). Hal tersebut didefinisikan bahwa jika faktorfaktor tertentu, penting untuk keberhasilan organisasi itu, tidak tercapai organisasi akan gagal (Huotari, 2001). Definisi lain tentang faktor penentu keberhasilan didefinisikan oleh Rockart (1979) yang menyoroti fakta bahwa faktor kunci kesuksesan adalah area manajemen yang terbatas di mana hasilnya, jika memuaskan, akan memastikan kinerja kompetitif yang sukses untuk organisasi. Salah satu teori yang komprehensif dalam mendefinisikan faktor kunci kesuksesan didefinisikan oleh Tuominen (1996) yang menyatakan bahwa faktor kunci kesuksesan adalah karakteristik, kondisi atau variabel yang ketika dipertahankan, dan dikelola dengan benar dapat memiliki dampak signifikan pada keberhasilan perusahaan dalam industri tertentu. Secara keseluruhan, faktor kunci kesuksesan digambarkan sebagai sejumlah area di mana hasilnya memastikan berhasil kinerja kompetitif.

Beberapa penelitian sebelumnya telah mempelajari peran faktor kunci kesuksesan dalam manajemen rantai pasokan. Gunasekaran (2003) mengidentifikasi lima faktor kunci yang penting, yaitu perencanaan strategis, manajemen persediaan, transportasi perencanaan, perencanaan kapasitas, dan manajemen informasi. Studi lain yang dilakukan oleh Power et al., (2001) mempertimbangkan faktor keberhasilan dalam rantai pasokan dan mengidentifikasi tujuh variabel penentu yaitu manajemen (manajemen sumber daya manusia), teknologi berbasis komputer (manajemen informasi), manajemen sumber daya (manajemen persediaan), peningkatan berkelanjutan, hubungan dengan pemasok 
(kolaborasi), metodologi tepat waktu, dan pemanfaatan teknologi.

\section{Faktor Kunci Kesuksesan Manajemen Rantai Pasokan Bencana Alam}

Seperti halnya rantai pasokan pada organisasi komersial, dalam bencana alam juga terdapat faktor-faktor kunci tertentu yang akan menentukan keberhasilan manajemen rantai pasokan utama dalam operasi bantuan bencana. Manajemen rantai pasokan bencana alam yang berhasil mampu meringankan kebutuhan populasi korban bencana yang mendesak dengan jumlah waktu terpendek dan dengan penggunaan sumber daya yang optimal (Tomasinia, 2004).

Samii et al., (2002) mengidentifikasi beberapa faktor yang akan membuat manajemen rantai pasokan yang sukses dalam operasi bantuan bencana, yaitu :

a. Sumber daya manusia

b. Manajemen pengetahuan

c. Manajemen proses dan operasi

d. Sumber daya keuangan

e. Kerjasama antara pemerintah, masyarakat dan swasta

\section{METODE PENELITIAN}

\section{Sampel dan Teknik Pengambilan Sampel}

Studi ini dilakukan dalam metodologi kualitatif deskriptif dengan metode wawancara mendalam tidak terstruktur (unstructured in-depth interview atau openended interview) untuk mendeskripsikan, meng-gambarkan faktor kunci keberhasilan manajemen rantai pasokan bencana alam secara sistematis, faktual, dan akurat. Sampel dalam penelitian ini adalah purposive sample, dimana responden yang dipilih sebagai sampel adalah perwakilan dari pembuat keputusan organisasi terkait dengan manajemen rantai pasokan dalam operasi bencana alam. Data primer dikumpulkan melalui wawancara dengan perwakilan dari Bagian Logistik pada
Kantor BPBD yang ada di Provinsi Daerah Istimewa Yogyakarta.

Dari lima kantor BPBD yang ada di Provinsi Daerah Istimewa Yogyakarta, empat kantor bersedia untuk menjadi narasumber dalam penelitian ini yaitu: (1) BPBD Provinsi Daerah Istimewa Yogyakarta sebagai Narasumber 1, (2) BPBD Kabupaten Sleman sebagai Narasumber 2, (3) BPBD Kabupaten Bantul sebagai Narasumber 3, dan (4) BPBD Kota Yogyakarta sebagai Narasumber 4. Hasil wawancara dari keempat narasumber tersebut kemudian diolah melalui lima tahapan metode analisis isi untuk kemudian dilakukan analisis faktor kunci keberhasilan dalam manajemen rantai pasokan bencana alam.

Adapun lima tahapan yang dilakukan dalam melakukan analisis isi faktor kunci keberhasilan dalam penelitian ini, yaitu:

1. Penentuan lingkup aktivitas, dimana pada penelitian ini ditetapkan pada lingkup operasional BPBD di Provinsi Daerah Istimewa.

2. Pengumpulan data melalui wawancara mendalam dengan narasumber.

3. Pengategorian data hasil wawancara (data mentah) untuk kemudian diturunkan menjadi sumber penentu faktor kunci keberhasilan.

4. Penurunan (derivative) sumber faktor kunci keberhasilan menjadi lebih ringkas dan jelas sehingga lebih mudah diimplementasikan.

5. Penetapan faktor kunci keberhasilan untuk kemudian digunakan sebagai informasi dan bahan pertimbangan dalam menentukan strategi manajemen rantai pasokan bencana alam di masa mendatang.

\section{HASIL PENELITIAN DAN PEMBAHASAN}

\section{Hasil Penelitian}

Proses menganalisis data dilakukan dengan merujuk pada transkrip sebagai 
hasil wawancara mendalam yang mengacu pada faktor-faktor kesuksesan manajemen rantai pasokan pada bencana alam yang sudah dikerjakan. Hal yang pertama dilakukan adalah mengembangkan pernyataan aktivitas (activity statement). Pernyataan aktivitas adalah pernyataan dari catatan wawancara dan dokumen yang mencerminkan apa yang narasumber lakukan atau yang mereka percaya harus dilakukan untuk memastikan keberhasilan rantai pasokan bencana alam dikerjakan. Pernyataan aktivitas secara kolektif menggambarkan tujuan dan sasaran operasional serta kegiatan yang dilakukan oleh responden mendukung tercapainya faktor kunci kesuksesan (Caralli et al., 2004).

Berdasarkan hasil wawancara dengan empat narasumber didapatkan 34 pernyataan aktivitas terkait manajemen rantai pasokan bencana alam. Pernyataan aktivitas tersebut kemudian dikelompokkan ke dalam kelompok kata kunci dan tema pendukung yang mengatur ide-ide, pikiran, konsep, dan lain-lain, sehingga deskripsi umum dari data dapat dikembangkan (Caralli et al., 2004). Rincian kata kunci dan tema pendukung terdapat pada tabel 1 berikut:

\section{Tabel 1. Rincian Kata Kunci dan Tema} Pendukung

\begin{tabular}{|l|l|l|}
\hline No & Kata Kunci & Tema Pendukung \\
\hline 1 & Koordinasi & $\begin{array}{l}\text { Koordinasi antar intansi } \\
\text { dan pihak yang terkait } \\
\text { dalam penanganan } \\
\text { bencana (14) }\end{array}$ \\
\hline & & $\begin{array}{l}\text { Kemampuan BPBD } \\
\text { sebagai pemegang } \\
\text { komando dan leading } \\
\text { sector dalam Manajemen } \\
\text { pencegahan, penanganan } \\
\text { dan pemulihan bencana } \\
(14)\end{array}$ \\
\hline 2 & $\begin{array}{l}\text { Penilaian } \\
\text { Assessment) }\end{array}$ & $\begin{array}{l}\text { Kemampuan } \\
\text { kompetensi anggota Tim } \\
\text { Reaksi Cepat (TRC) } \\
\text { dalam melakukan }\end{array}$ \\
\hline
\end{tabular}

\begin{tabular}{|c|c|c|}
\hline & & $\begin{array}{lr}\text { pendataan } & \text { kebutuhan } \\
\text { masyarakat } & \text { terdampak } \\
\text { bencana di } & \text { kondisi } \\
\text { tanggap darurat } & (43)\end{array}$ \\
\hline & & $\begin{array}{l}\text { Training dan pelatihan } \\
\text { rutin bagi anggota TRC }\end{array}$ \\
\hline 3 & $\begin{array}{l}\text { Peraturan dan } \\
\text { Regulasi }\end{array}$ & $\begin{array}{l}\text { Seperangkat peraturan } \\
\text { maupun regulasi dari } \\
\text { pemerintah regulasi baik } \\
\text { dari pemerintah pusat, } \\
\text { provinsi, maupun } \\
\text { kabupaten/kota terkait } \\
\text { prosedur operasional dan } \\
\text { tata kelola BPBD dalam } \\
\text { Manajemen Bencana (12) }\end{array}$ \\
\hline \multirow[t]{2}{*}{4} & $\begin{array}{l}\text { Pengadaan } \\
\text { barang }\end{array}$ & $\begin{array}{l}\text { Sistem pengadaan barang } \\
\text { bantuan (pangan, non- } \\
\text { pangan, dan peralatan) } \\
\text { melalui lelang di masa } \\
\text { pra bencana dan } \\
\text { penunjukkan langsung di } \\
\text { masa tanggap darurat } \\
(20)\end{array}$ \\
\hline & & $\begin{array}{l}\text { Akses atas Dana Siap } \\
\text { Pakai atau Dana Tidak } \\
\text { Terduga untuk pengadaan } \\
\text { barang bantuan } \\
\text { dikeleluarkan } \\
\text { bencana oleh Kepala } \\
\text { Daerah (5) }\end{array}$ \\
\hline \multirow[t]{2}{*}{5} & Buffer stock & $\begin{array}{l}\text { Manifest penerimaan dan } \\
\text { pencatatan/stock opname } \\
\text { atas buffer stock yang ada } \\
\text { di Gudang milik BPBD } \\
\text { (3) }\end{array}$ \\
\hline & & $\begin{array}{l}\text { Manajemen persediaan } \\
\text { dan Manajemen kualitas } \\
\text { atas buffer stock yang ada } \\
\text { di Gudang milik BPBD } \\
\text { (22) }\end{array}$ \\
\hline 6 & $\begin{array}{l}\text { Pembaharuan } \\
\text { data }\end{array}$ & $\begin{array}{l}\text { Sistem } \\
\text { Manajemen yang } \\
\text { mencakup real time data } \\
\text { and information yang } \\
\text { dapat diakses oleh BPBD } \\
\text { dan pihak lain yang }\end{array}$ \\
\hline
\end{tabular}


POPPY LAKSITA RINI

Faktor Kunci Keberhasilan Manajemen Rantai Pasokan Penanganan Bencana Alam dalam Perspektif Pemerintah

\begin{tabular}{|c|c|c|}
\hline & & $\begin{array}{l}\text { terkait dengan } \\
\text { penanganan bencana (24) }\end{array}$ \\
\hline 7 & $\begin{array}{l}\text { Kerjasama } \\
\text { pihak swasta }\end{array}$ & $\begin{array}{l}\text { Keterlibatan pihak publik } \\
\text { atau swasta dalam } \\
\text { operasional Manajemen } \\
\text { bencana } \\
\text { Manajemen persediaan } \\
\text { bantuan dan Manajemen } \\
\text { distribusi bantuan (9) }\end{array}$ \\
\hline 8 & $\begin{array}{l}\text { Monitoring } \\
\text { dan evaluasi }\end{array}$ & $\begin{array}{l}\text { Sistem monitoring } \\
\text { evaluasi yang dilakukan } \\
\text { oleh BPBD pasca } \\
\text { bencana terjadi dan } \\
\text { melakukan perencanaan } \\
\text { untuk perbaikan } \\
\text { Manajemen penanganan } \\
\text { bencana (13) }\end{array}$ \\
\hline 9 & $\begin{array}{l}\text { Karakter } \\
\text { masyarakat } \\
\text { lokal }\end{array}$ & $\begin{array}{l}\text { Karakter dan local } \\
\text { wisdom yang telah dianut } \\
\text { atau menjadi budaya di } \\
\text { masyarakat (11) }\end{array}$ \\
\hline & & $\begin{array}{l}\text { Kesiapan masyarakat } \\
\text { dalam menghadapi } \\
\text { kondisi darurat dan pasca } \\
\text { bencana (19) }\end{array}$ \\
\hline
\end{tabular}

Sumber : Data primer diolah (2019)

Ket $\quad:(\ldots)^{\mathrm{a}}$ menunjukkan jumlah total pernyataan aktivitas yang mendukung tema pendukung ini.

Langkah terakhir dalam perumusan faktor kunci keberhasilan adalah menganalisis tema-tema pendukung. Sembilan kata kunci dengan empat belas tema pendukung tersebut kemudian dianalisis dimana tema-tema yang sejenis digabungkan menjadi satu faktor kunci keberhasilan sehingga didapatkan enam faktor kunci keberhasilan manajemen rantai pasokan bencana alam yang terangkum dalam tabel 2:

Tabel 2. Faktor Kunci Kesuksesan Manajemen Rantai Pasokan Bencana Alam pada BPBD

\begin{tabular}{|l|l|l|}
\hline No & Tema Pendukung & \multicolumn{1}{|c|}{$\begin{array}{c}\text { Faktor Kunci } \\
\text { Kesuksesan }\end{array}$} \\
\hline 1 & $\begin{array}{l}\text { Kemampuan dan } \\
\text { kompetensi anggota }\end{array}$ & $\begin{array}{l}\text { Kompetensi Tim } \\
\text { TRC }(51)^{\mathrm{b}}\end{array}$ \\
\hline
\end{tabular}

\begin{tabular}{|c|c|c|}
\hline & $\begin{array}{l}\text { Tim Reaksi Cepat } \\
(\mathrm{TRC}) \text { dalam } \\
\text { melakukan } \\
\text { pendataan } \\
\text { kebutuhan } \\
\text { masyarakat } \\
\text { terdampak bencana } \\
\text { di kondisi tanggap } \\
\text { darurat }(43)^{\mathrm{a}}\end{array}$ & \\
\hline & $\begin{array}{l}\text { Training dan } \\
\text { pelatihan rutin bagi } \\
\text { anggota TRC ( } 8 \text { ) }\end{array}$ & \\
\hline \multirow[t]{4}{*}{2} & $\begin{array}{l}\text { Koordinasi antar } \\
\text { intansi dan pihak } \\
\text { yang terkait dalam } \\
\text { penanganan } \\
\text { bencana (14) }\end{array}$ & \multirow[t]{4}{*}{$\begin{array}{lr}\text { Koordinasi } & \text { BPBD } \\
\text { dengan Intansi } \\
\text { Pemerintah dan } \\
\text { Non-Pemerintah } \\
(50)\end{array}$} \\
\hline & $\begin{array}{l}\text { Kemampuan BPBD } \\
\text { sebagai pemegang } \\
\text { komando dan } \\
\text { leading sector } \\
\text { dalam Manajemen } \\
\text { pencegahan, } \\
\text { penanganan dan } \\
\text { pemulihan bencana } \\
(14)\end{array}$ & \\
\hline & $\begin{array}{l}\text { Keterlibatan pihak } \\
\text { publik atau swasta } \\
\text { dalam operasional } \\
\text { Manajemen } \\
\text { bencana seperti } \\
\text { Manajemen } \\
\text { persediaan bantuan } \\
\text { dan Manajemen } \\
\text { distribusi bantuan } \\
(9)\end{array}$ & \\
\hline & $\begin{array}{lr}\text { Sistem monitoring } \\
\text { evaluasi } & \text { yang } \\
\text { dilakukan oleh } & \text { pasca } \\
\text { BPBD } & \text { pencana terjadi dan } \\
\text { melakukan } & \\
\text { perencanaan } & \text { untuk } \\
\text { perbaikan } & \\
\text { Manajemen } & \\
\text { penanganan } & \\
\text { bencana (13) } & \\
\end{array}$ & \\
\hline 3 & \begin{tabular}{l}
\multicolumn{2}{l}{ Seperangkat } \\
peraturan maupun \\
regulasi dari \\
pemerintah regulasi \\
baik dari \\
pemerintah pusat, \\
provinsi, maupun \\
kabupaten/kota \\
terkait prosedur \\
operasional dan tata \\
kelola BPBD dalam
\end{tabular} & $\begin{array}{lr}\text { Peraturan } & \text { dan } \\
\text { Regulasi } & \text { yang } \\
\text { Efektif (37) } & \end{array}$ \\
\hline
\end{tabular}




\begin{tabular}{|c|c|c|}
\hline & $\begin{array}{l}\text { Manajemen } \\
\text { Bencana (12) }\end{array}$ & \\
\hline & $\begin{array}{lr}\begin{array}{l}\text { Sistem } \\
\text { barang }\end{array} & \begin{array}{r}\text { pengadaan } \\
\text { (pangan, }\end{array} \\
\text { pangan, non- } & \text { dan } \\
\text { peralatan) melalui } & \text { man } \\
\text { lelang di masa pra } \\
\text { bencana } \\
\text { penunjukkan } \\
\text { langsung di masa } \\
\text { tanggap darurat } \\
(20)\end{array}$ & \\
\hline & $\begin{array}{lr}\text { Akses atas } & \text { Dana } \\
\text { Siap Pakai } & \text { atau } \\
\text { Dana } & \text { Tidak } \\
\text { Terduga } & \text { untuk } \\
\text { pengadaan } & \text { barang } \\
\text { bantuan } & \text { setelah } \\
\text { dikeluarkan } & \text { status } \\
\text { bencana } & \text { oleh } \\
\text { Kepala Daerah }(5) \\
\end{array}$ & \\
\hline \multirow[t]{2}{*}{4} & $\begin{array}{l}\text { Karakter dan local } \\
\text { wisdom yang telah } \\
\text { dianut atau menjadi } \\
\text { budaya di } \\
\text { masyarakat (11) }\end{array}$ & \multirow[t]{2}{*}{$\begin{array}{l}\text { Karakter dan Sikap } \\
\text { Masyarakat dalam } \\
\text { Menghadapi } \\
\text { Bencana (30) }\end{array}$} \\
\hline & $\begin{array}{l}\text { Kesiapan } \\
\text { masyarakat dalam } \\
\text { menghadapi } \\
\text { kondisi darurat dan } \\
\text { pasca bencana (19) }\end{array}$ & \\
\hline 5 & $\begin{array}{l}\text { Manifest } \\
\text { penerimaan dan } \\
\text { pencatatan/stock } \\
\text { opname atas buffer } \\
\text { stock yang ada di } \\
\text { Gudang milik } \\
\text { BPBD (3) }\end{array}$ & \multirow[t]{2}{*}{$\begin{array}{l}\text { Manajemen } \\
\text { Persediaan Gudang } \\
\text { BPBD }(25)\end{array}$} \\
\hline & $\begin{array}{l}\text { Manajemen } \\
\text { persediaan dan } \\
\text { Manajemen } \\
\text { kualitas atas } \text { buffer } \\
\text { stock yang ada di } \\
\text { Gudang milik } \\
\text { BPBD (22) }\end{array}$ & \\
\hline 6 & $\begin{array}{l}\text { Sistem informasi } \\
\text { Manajemen yang } \\
\text { mencakup real time } \\
\text { datarand } \\
\text { information yang } \\
\text { dapat diakses oleh } \\
\text { BPBD dan pihak } \\
\text { lain yang terkait } \\
\text { dengan penanganan } \\
\text { bencana (24) }\end{array}$ & $\begin{array}{l}\text { Sistem Informasi } \\
\text { Manajemen dan } \\
\text { Update Data (24) }\end{array}$ \\
\hline
\end{tabular}

Sumber : Data primer diolah (2019)

Ket $\quad:(\ldots)^{\mathrm{a}}$ menunjukkan jumlah total pernyataan aktivitas yang mendukung tema pendukung ini. $(\ldots)^{\mathrm{b}}$ menunjukkan jumlah total pernyataan aktivitas yang mendukung faktor kunci ini.

\section{Pembahasan}

\section{Kompetensi Tim Reaksi Cepat}

Upaya penyelamatan masyarakat terkena bencana dilaksanakan oleh Tim Reaksi Cepat (TRC) Penanggulangan Bencana. Menurut PERKA nomor 13 Tahun 2010, Tim Reaksi Cepat (TRC) adalah tim yang terdiri dari petugaspetugas yang memiliki kualifikasi dalam melakukan, pencarian, pertolongan, dan evakuasi korban bencana. Salah satu tugas utama TRC begitu terjadi kondisi tanggap darurat bencana adalah melakukan penilaian (assessment) atas dampak dan korban bencana, serta melakukan identifikasi kebutuhan baik pangan, non-pangan, maupun peralatan bagi korban dan lokasi bencana. Untuk itu kualitas hasil assessment dari TRC ini sangatlah penting untuk menentukan apa dan bagaimana rantai pasokan bantuan akan dilakukan. Hasil assessment ini haruslah tepat dan cepat sebagai langkah pertama dalam penyaluran bantuan ke lokasi dan korban bencana. Hal ini sebagaimana pernyataan dari narasumber berdasarkan hasil wawancara mendalam.

"Bantuan kita berikan ke kelompok masyarakat berdasarkan hasil assessment oleh Tim TRC tadi ya. Kelompok apa butuhnya apa berapa jumlahnya lokasinya dimana. Assessment ini penting karena untuk memastikan pengelolaan logistic bantuan bencana alam ini efektif dan efisien, tidak berlebih tidak kurang" (Narasumber 2, 2019).

\section{Koordinasi BPBD dengan Intansi Pemerintah dan Non-Pemerintah}

Dalam kondisi tanggap darurat, kemampuan BPBD sebagai leading sector untuk memegang komando dan koordinasi sangat penting dalam manajemen rantai pasokan penyaluran bantuan ke korban dan lokasi bencana. 
Hal ini dikarenakan, banyaknya pihak yang turut terlibat dalam alur proses rantai pasokan baik secara langsung maupun tidak langsung, baik secara formal maupun informal. Efektivitas dan efisiensi distribusi dan rantai pasokan bantuan ditentukan oleh koordinasi yang dilakukan BPBD dengan lintas intansi pemerintah, non-pemerintah, dan masyarakat.

"Kami juga merasa perlu adanya koordinasi dan konsolidasi lintas sector atau lintas instansi itu juga penting. Karena setiap instansi ini punya standar operasional prosedur (SOP) dan budaya kerja mereka sendiri-sendiri. Menyatukan yang berbeda-beda ini saat terjadi bencana alam ini sangat sulit dan jadi tantangan tersendiri bagi kami $B P B D$ Provinsi sebagai leading sector nya karena harus mengesampingkan ego, menyamakan misi satu komando untuk kemanusiaan"'(Narasumber 1, 2019).

\section{Peraturan dan Regulasi yang Efektif}

Sebagai intansi pemerintah, setiap kegiatan operasional yang dilakukan oleh BPBD haruslah sesuai dengan peraturan dan regulasi yang berlaku baik dari tingkat nasional, provinsi, maupun kabupaten atau kota. Hal ini penting dalam Manajemen rantai pasokan bencana supaya setiap aktivitas yang dilakukan BPBD sebagai instansi pemerintahan selalu berorientasi pada terciptanya tata kelola intansi yang baik (good corporate governance).

"Semuanya juga tentunya didukung oleh tata regulasi dan peraturan tentang Manajemen logistik tanggap bencana. Itu semua sudah ada, sehingga jika kita harus melakukan pengadaan, penyaluran, dan lain-lain itu tata kelolanya sudah jelas. Itu semuanya sudah diatur cara-caranya tinggal implementasi lapangannya sesuai tidak dengan peraturan tersebut." (Narasumber 4, 2019).

\section{Karakter dan Sikap Masyarakat dalam Menghadapi Bencana}

Dalam kondisi tanggap darurat bencana, masyarakat merupakan konsumen akhir (end customer) bagi pelayanan dan jasa yang diberikan oleh BPBD, sehingga perilaku masyarakat merupakan faktor penting dalam menentukan kepuasan masyarakat atas pelayanan dan jasa yang diberikan oleh BPBD. Karakter dan sikap masyrakat yang kooperatif dengan pemerintah di tengah situasi bencana akan lebih memudahkan BPBD dalam melakukan kegiatan operasionalnya di lokasi bencana.

"Jadi masyarakat di Yogyakarta karakternya saling bergotong royong. Kalau ada tetangga yang kesulitan akan sangat sigap membantu. Itulah mengapa proses penanganan bencana alam di DIY ini bisa berlangsung dengan cepat, karena tadi ada bantuan dari masyarakat. Ini juga memudahkan dalam proses penyaluran logistic bantuan dan peralatan di lokasi bencana" (Narasumber 3, 2019).

\section{Manajemen Persediaan di Gudang BPBD}

Pada kondisi pra bencana, BPBD akan menyimpan beberapa jenis barang bantuan pada Gudang-gudang milik BPBD sebagai buffer stock. Bantuan tersebut sifatnya siap pakai sehingga begitu terjadi bencana, maka buffer stock tersebut akan langsung diluncurkan ke lokasi bencana. Manajemen persediaan untuk menentukan jenis barang apa, berapa jumlahnya, dan kapan barang harus di restock maupun di keluarkan dari gudang menjadi faktor penting karena berhubungan dengan ketepatan dan kecepatan penyaluran bantuan di masa-masa awal terjadinya bencana. Semakin tepat jenis dan jumlah barang bantuan yang tersedia di Gudang BPBD, maka semakin cepat bantuan tersebut 
dapat disalurkan ke masyarakat di lokasi bencana.

Selain melakukan kontrol atas jenis dan jumlah persediaan, BPBD juga senantiasa menjaga kualitas atas buffer stock yang ada di gudang. Beberapa jenis persediaan merupakan barang yang memiliki waktu kadaluwarsa seperti pangan dan obat-obatan, sehingga BPBD secara rutin melakukan kontrol kualitas atas persediaan yang ada. BPBD Provinsi dan BPBD Bantul bahkan menggandeng rekanan swasta dalam melakukan kontrol kualitas buffer stock di gudang guna memastikan persediaan bantuan yang dimiliki selalu dalam kualitas yang baik.

\section{Sistem Informasi Manajemen Bencana Alam}

BPBD selalu mengupayakan pembaharuan atas data dan informasi terkait penanganan bencana, baik itu data dan informasi yang dimiliki oleh BPBD sendiri maupun yang dimiliki oleh intansi lain yang berkaitan dengan operasional rantai pasokan penanganan bencana alam. Hal ini merupakan faktor yang penting karena dalam melakukan Manajemen rantai pasokan penanganan bencana, BPBD harus bertindak secara cepat, tepat, dan akurat, sehingga ketersediaan data dan informasi yang update dan dapat diakses secara real time oleh berbagai pihak tidak hanya akan membantu BPBD dalam pengambilan keputusan terkait operasional penanganan bencana, tetapi juga memudahkan koordinasi BPBD dengan pihak lain yang terlibat dalam penanganan bencana baik secara langsung maupun tidak langsung.

Gambar 1 berikut menunjukkan model tulang ikan (fishbone model) faktor kunci kesuksesan Manajemen rantai pasokan bencana alam dalam perspektif pemerintah di BPBD Provinsi dan Kabupaten atau Kota di Daerah Istimewa Yogyakarta.

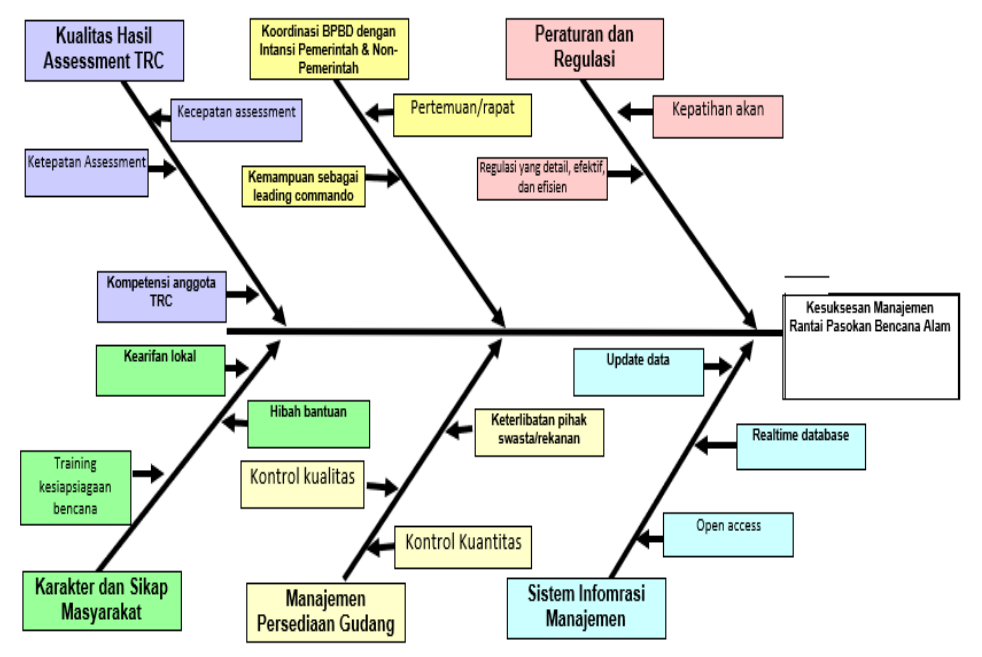

Gambar 1. Model tulang ikan (fishbone model) faktor kunci kesuksesan Manajemen rantai pasokan bencana alam.

\section{KESIMPULAN DAN SARAN}

\section{Kesimpulan}

Penelitian ini bertujuan untuk mengidentifikasi faktor-faktor kunci kesuksesan dalam Manajemen rantai pasokan bencana alam pada BPBD Provinsi dan Kabupaten atau Kota di Provinsi Daerah Istimewa Yogyakarta. Berdasarkan hasil wawancara mendalam dengan empat perwakilan BPBD, ditemukan enam faktor kunci keberhasilan dalam manajemen rantai pasokan bencana alam, yaitu: (1) Kompetensi Tim TRC; (2) Koordinasi BPBD dengan Intansi Pemerintah dan Non-Pemerintah; (3) Peraturan dan Regulasi yang Efektif; (4) Karakter dan Sikap Masyarakat dalam Menghadapi Bencana; (5) Manajemen Persediaan Gudang BPBD; (6) Sistem Informasi Manajemen dan Update Data. Kedepannya diharapkan operasional manajemen rantai pasokan BPBD di Provinsi DIY mampu lebih difokuskan pada keputusan yang mengarah pada faktor penentu keberhasilan tersebut.

\section{Saran}

Penelitian ini hanya memotret faktor kunci keberhasilan manajemen rantai 
pasokan bencana alam dari perspektif pemerintah dalam hal ini adalah BPBD. Penelitian selanjutnya disarankan untuk memotret dampak manajemen rantai pasokan bencana pada pemerintah terhadap masyarakat dan korban bencana. Selain itu, faktor kunci keberhasilan manajemen rantai pasokan bencana dari perspektif swasta maupun masyarakat juga dapat menjadi pengembangan ranah penelitian ini, sehingga akan didapatkan gambaran yang komprehensif dari perspektif pemerintah, swasta, dan masyarakat mengenai apa yang menjadi faktor keberhasilan suatu manajemen rantai pasokan dalam kondisi bencana. Dengan berfokus pada faktor kunci keberhasilan, diharapkan operasional manajemen rantai pasokan pada kondisi bencana dapat semakin efektif dan efisien.

\section{DAFTAR PUSTAKA}

Caralli, R. A., Stevens, J. F., Willke, B. J., \& Wilson, W. R. (2004). The Critical Success Factor Method: Establishing a Foundation for Enterprise Security Management. Technical Report, Carnegie Mellon Universtity, Software Engineering Institute, Pittsburg.

Christopher, M. and Towill, D. (2001). An integrated model for the design of agile supply chains. International Journal of Physical Distribution \& Logistics Management, Vol. 31 No. 4, pp. 235-246.

Daniel, D. R. (1961). Management Information Crisis. Harvard Business Review, 39(5), 111-116.

Gattorna, J. (2006). Living Supply Chains: How to Mobilize the Enterprise Around Delivering what Your Customers Want. Financial Times Prentice Hall.
Gunasekaran, A. and Ngai, E.W.T., (2003). The successful management of a small logistics company. International Journal of Physical Distribution \& Logistics Management, Vol. 33 No. 9, pp. 82542.

Heizer, J. dan B. Render. (2011). Priciples of Operations Management. United States of America. Pearson: 698 p

Huotari, M.-L. and Wilson, T.D., (2001). Determining organisational information needs: the critical success factors approach. Information Research, Vol. 6 No. 3, pp. 109-187.

Power, D.J., Sohal, A.S. and Rahman, SU., (2001). Critical success factors in agile supply chain management. International Journal of Physical Distribution \& Logistics Management, Vol. 31 No. 4, pp. 24765.

Rockart, J.F., (1979). Chief executives define their own data needs. Harvard Business Review, Vol. 57 No. 2, pp. 238-41.

Samii R., Van Wassenhove L. N., Kumar $\mathrm{K}$ and Becerra-Fernandez I., (2002). Choreographer of disaster management: preparing for tomorrow's disasters. No.06/20025039. INSEAD, Fontainebleau, France.

Schulz, S.F. and Heigh, I., (2007). Logistics performance management in action - design and piloting of a development indicator tool for regional logistics units of IFRC. Proceedings of the 1st CardiffCranfield Humanitarian Logistics Initiative Conference, Shrivenham. 
Tomasinia, R.M. and Van Wassenhove L.N., (2004). A framework to unravel, prioritize and coordinate vulnerability and complexity factors affecting a humanitarian response operation. Working Paper No.2004/41/TM. INSEAD, Fontainebleau, France.

Tomasinia, R.M and Wassenhove, L.N., (2009). From preparedness to partnerships: case study research on humanitarian logistics. International Journal in Operation Research, Volume 16 (1), pp. 549-559.

Tuominen, M. and Korperla, J. (1996). A decision support system for strategic issues management of logistics. International Journal of Production Economics, vol. 46-47 (1), pp. 605620.

UNDP. (1993). Logistics, 1st ed., United Nations Development Programme, Geneva 